\title{
Review \\ Disrupting GPCR Complexes with Smart Drug-like Peptides
}

\author{
Maria Gallo $\mathbb{D}$, Sira Defaus*(i) and David Andreu* \\ Department of Experimental and Health Sciences, Pompeu Fabra University, Barcelona Biomedical Research Park, \\ 08003 Barcelona, Spain; maria.gallo@upf.edu \\ * Correspondence: sira.defaus@upf.edu (S.D.); david.andreu@upf.edu (D.A.); Tel.: +34-933160868 (S.D. \& D.A.)
}

Citation: Gallo, M.; Defaus, S.; Andreu, D. Disrupting GPCR Complexes with Smart Drug-like Peptides. Pharmaceutics 2022, 14, 161. https://doi.org/10.3390/pharmaceutics 14010161

Academic Editors:

Benjamí Oller-Salvia and

Noriyasu Kamei

Received: 1 December 2021

Accepted: 5 January 2022

Published: 11 January 2022

Publisher's Note: MDPI stays neutral with regard to jurisdictional claims in published maps and institutional affiliations.

Copyright: (C) 2022 by the authors. Licensee MDPI, Basel, Switzerland. This article is an open access article distributed under the terms and conditions of the Creative Commons Attribution (CC BY) license (https:// creativecommons.org/licenses/by/ $4.0 /)$.

\begin{abstract}
G protein-coupled receptors (GPCRs) are a superfamily of proteins classically described as monomeric transmembrane (TM) receptors. However, increasing evidence indicates that many GPCRs form higher-order assemblies made up of monomers pertaining to identical (homo) or to various (hetero) receptors. The formation and structure of these oligomers, their physiological role and possible therapeutic applications raise a variety of issues that are currently being actively explored. In this context, synthetic peptides derived from TM domains stand out as powerful tools that can be predictably targeted to disrupt GPCR oligomers, especially at the interface level, eventually impairing their action. However, despite such potential, TM-derived, GPCR-disrupting peptides often suffer from inadequate pharmacokinetic properties, such as low bioavailability, a short half-life or rapid clearance, which put into question their therapeutic relevance and promise. In this review, we provide a comprehensive overview of GPCR complexes, with an emphasis on current studies using GPCR-disrupting peptides mimicking TM domains involved in multimerization, and we also highlight recent strategies used to achieve drug-like versions of such TM peptide candidates for therapeutic application.
\end{abstract}

Keywords: peptide therapeutics; transmembrane peptides; GPCR oligomers; non-natural amino acids; cyclic peptides; retro-enantio

\section{Introduction}

G protein-coupled receptors (GPCRs) constitute the largest and most versatile superfamily of cell membrane-bound proteins, made up of seven trans-membrane $\alpha$-helices (TM1 to TM7) [1-3] connected by intracellular (IL-1 to IL-3) and extracellular loops (EL-1 to EL-3), and coupled to an intracellular heterotrimeric G protein (e.g., Gs, Gi/o, Gq/11, G12/13) [4]. GPCRs are commonly grouped into six subfamilies (A-F) [5], based on sequence homology and functionality. Despite this apparent diversity, all GPCRs mediate their effects upon agonist-induced activation of the receptor at the extracellular site by a wide variety of ligands and then transduce the signal into intracellular responses [6]. Endogenous GPCR agonists are physically and chemically very diverse, including neurotransmitters (i.e., dopamine, serotonin), hormones (i.e., estrogen, angiotensin), proteins (i.e., chemokines), odors, photons, lipids (i.e., anandamide) or peptides (i.e., bradykinin), among many others [7]. Moreover, and more interestingly, ligand affinity for the GPCR primary (orthosteric) site and efficacy of activation can be increased or decreased by other effectors that bind to a separate (allosteric) site [8].

Given that GPCR signaling is involved in a diverse number of biological processes, GPCRs are considered ideal therapeutic targets [9] for a wide assortment of human diseases ranging from allergic rhinitis to pain, type-2 diabetes mellitus, obesity, depression, insomnia or cancer, to name just a few [10-12]; indeed, 34\% of currently FDA-approved smallmolecule drugs bind to GPCRs [13]. Originally described as cell-surface monomers that form a ternary complex with the extracellular ligand and the intracellular G protein [14], GPCR higher-order oligomers have in recent years been increasingly recognized as novel signaling units with functional properties distinct from their constituent receptors, thus 
opening up a new, only sparingly explored area of study within the GPCR field [15,16]. One possible strategy to probe into GPCR oligomerization and its impact on health conditions would consist in interfering in complex formation by means of exogenous synthetic peptides replicating TM domains involved in helix-helix interactions [17].

In this review, we consider the challenges and opportunities involved in disrupting GPCR oligomer formation by means of TM peptides targeting the complex interface, as a way to regulate oligomerization-dependent functions, and we also discuss strategies reported to improve the druggability of such peptide candidates in the context of cannabinoid-mediated pain management or CNS disorders.

\section{GPCR Oligomers}

The human genome encodes nearly 1000 different GPCRs, each one highly specific to a signaling pathway [18]. However, growing evidence indicates that many GPCRs can form active higher-order oligomers constituted by equal (homo) or different (hetero) monomers [19-26], with functional properties distinct from their protomer components [27] and generally involved in both healthy and pathological processes [28], thus making them ideal targets for the development and screening of novel drugs [29,30].

One of the first reported GPCR oligomers involved $\delta$ - and $\kappa$-opioid receptors that, when co-expressed, formed a stable heterodimer with properties not found in cells expressing the same receptor monomers [31]. Subsequently, many other GPCR homo- and/or hetero-complexes have been unveiled, often displaying unique characteristics.

In many of these investigations the importance of TM helices in GPCR oligomerization has been demonstrated, portraying the GPCR complexes as dynamic species in which activation by the agonist induces a realignment of TM dimerization interfaces [32,33]. Indeed, it has been found that a dynamic equilibrium between monomeric and dimeric species can take place [34], modulated by ligand binding, which in turn can enhance or decrease heteromer interaction [35]. Therefore, while the minimal GPCR functional unit can be regarded as constituted by one monomeric receptor and one heterotrimeric $G$ protein (1:1) [36], GPCR dimers can occur when: (i) two G proteins bind both dimer protomers $(2: 2)[37,38]$ or (ii) one $G$ protein binds one protomer in the dimer (1:2) [39].

Another distinctive feature of some GPCRs is the switching of the G protein-coupled protomer when dimerization occurs. For instance, serotonin $5 \mathrm{HT}_{2 \mathrm{~A}} \mathrm{R}$ couples $\mathrm{Gq}$; however, heteromer formation by cannabinoid $\mathrm{CB}_{1} \mathrm{R}$ and $5 \mathrm{HT}_{2 \mathrm{~A}} \mathrm{R}$ makes both receptors signal via Gi [40] (Figure 1A). In other words, some GPCR heteromers can couple G protein species different from those favoured by their protomers. Other reported examples are: (i) a heterodimer formed by dopamine $\mathrm{D}_{1}$ and $\mathrm{D}_{2}$ receptors that couples $\mathrm{Gq}$ instead of $\mathrm{Gs}$ or Gi [41] (Figure 1B); (ii) the heteromer formed by angiotensin $\mathrm{AT}_{1}$ and $\alpha_{2 \mathrm{c}}$-adrenergic receptors couples $\mathrm{Gs}$ instead of $\mathrm{Gi}$ or $\mathrm{Gq}$ [42]; and (iii) a melatonin $\mathrm{MT}_{1}-\mathrm{MT}_{2}$ receptor dimer that couples Gq instead of Gi [43].

Functionally, GPCR complexes can cause a positive or negative cooperation between promoters, i.e., ligand one binds to protomer one, enhancing or inhibiting, respectively, the affinity of ligand two for protomer two [44]. In general, intermolecular communication between GPCR homo- and heteromers tends to produce synergistic responses (i.e., functional cross-talk) [45]. A more singular phenomenon is cross-antagonism (Figure 1C), which occurs when a protomer antagonist blocks the signal activation of the other protomer $[25,40,45]$. Such a situation has been described for some GPCR complexes, including the metabotropic $\mathrm{Gb}_{1}-\mathrm{Gb}_{2}$ receptors [46], opioid $\delta$ - $\mu$ receptors [47], somatostatin $\mathrm{SST}_{5}$-dopamine $\mathrm{D}_{2}$ receptors [48], adenosine $\mathrm{A}_{2} \mathrm{~A}$-dopamine $\mathrm{D}_{1}$ receptors [49], orexincorticotropin-releasing factor receptor [50] or angiotensin II $\mathrm{AT}_{1} /$ dopamine $\mathrm{D}_{2}$ receptor [51]. 
A

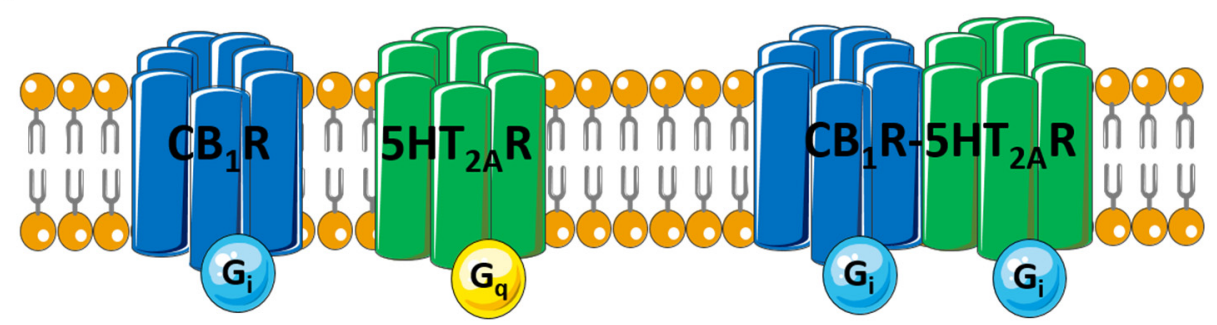

B

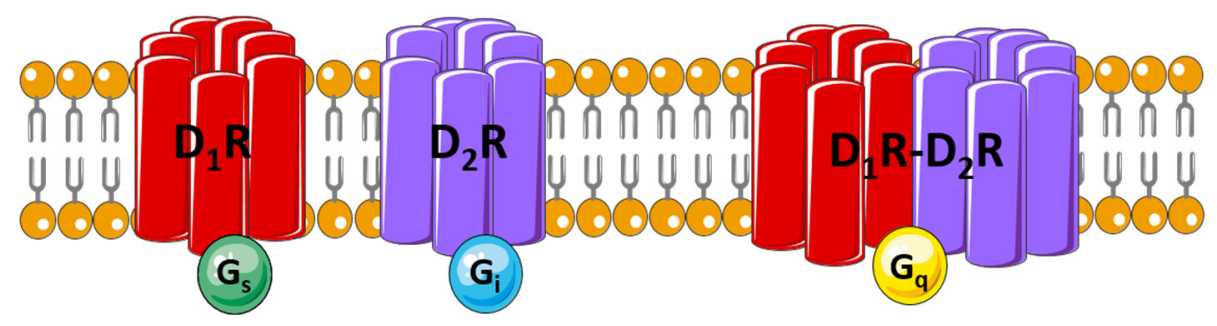

C

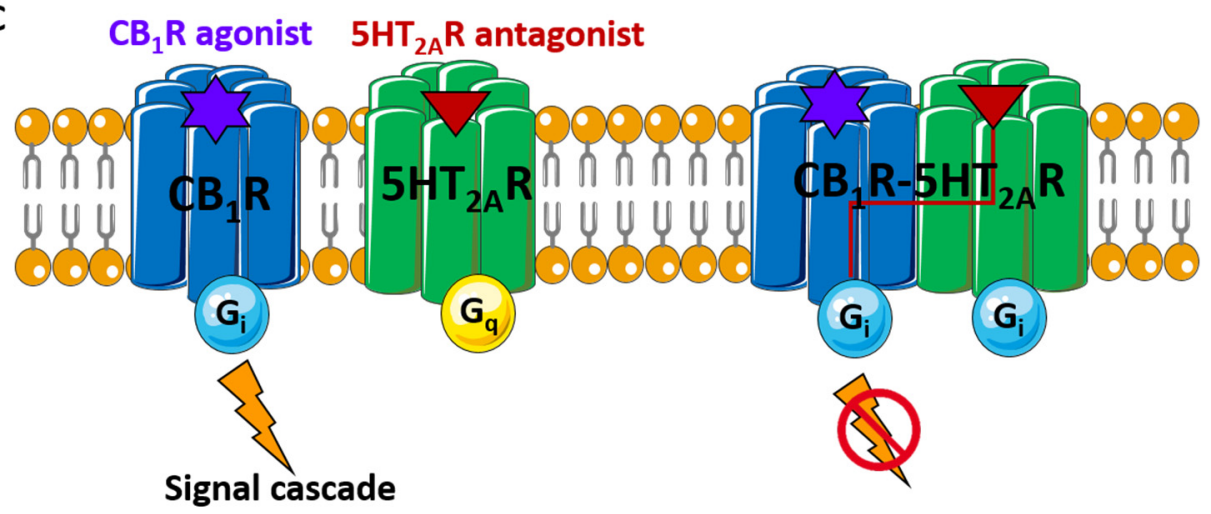

Figure 1. (A) The serotonin $5 \mathrm{HT}_{2 \mathrm{~A}} \mathrm{R}$ and the cannabinoid $\mathrm{CB}_{1} \mathrm{R}$ monomers couple $\mathrm{Gi}$ and $\mathrm{Gq}$ proteins, respectively; when dimerized, however, $5 \mathrm{HT}_{2 \mathrm{~A}} \mathrm{R}$ switches $\mathrm{Gq}$ protein with $\mathrm{Gi}$; (B) The dopamine $\mathrm{D}_{1} \mathrm{R}$ and $\mathrm{D}_{2} \mathrm{R}$ monomers couple $\mathrm{Gs}$ or $\mathrm{Gi}$, respectively; however, the heterodimer $\mathrm{D}_{1} \mathrm{R}-\mathrm{D}_{2} \mathrm{R}$ couples $\mathrm{Gq}$; (C) The serotonin $5 \mathrm{HT}_{2 \mathrm{~A}} \mathrm{R}$ antagonist blocks the signal activation of the cannabinoid $\mathrm{CB}_{1} \mathrm{R}$ agonist when dimerized.

Despite the extensive literature on GPCR oligomers, in most cases the assessment of their functionality has been only partially addressed and needs further investigation. In this context, chimeric peptide constructs have shown the ability to disrupt homo- and heteromer complexes, altering agonist-induced functionality and providing knowledge on the physiological role of GPCR receptor-receptor interactions [52-55].

\section{Synthetic TM Peptides as Tools for GPCR Complex Exploration}

The identification of protein-protein interaction interfaces constitutes a fundamental aspect in the study of GPCR complex formation [56], in that it can expand our understanding of the role that receptor oligomerization plays in intercellular communication or in some pathological conditions.

Increasing evidence indicates that specific TM helices are required for oligomerization, and that the synthetic peptides reproducing them are powerful tools to identify sequences essential for GPCR complexation and, by blocking their assembly, gain insights into the functional role of the complex $[52,57,58]$.

For instance, Köfalvi et al. (2020) have recently studied how the adenosine-cannabinoid receptors, specifically the $A_{2 A} R-C B_{1} R$ heterotetramer interface, which also includes $A_{2 A} R$ - 
$A_{2 A} R$ and $C B_{1} R-C B_{1} R$ homodimers, is established. To this end they have used computational modelling, with input from several biophysical and biochemical techniques, to design TM interference peptides reproducing each of the $A_{2 A} R$ and $C B_{1} R$ TM1-7 helices. The synthetic versions, fused to the cell-penetrating HIV-Tat sequence, were tested by in vitro bimolecular fluorescence complementation (BiFC) experiments. Peptides replicating TM5 and TM6 of both receptors were able to disrupt the heterotetramer; thus, the involvement of their interfaces in the complex formation was confirmed. On the other hand, in the absence of the $\mathrm{CB}_{1} \mathrm{R}$ receptor, $\mathrm{BiFC}$ assays showed that the $\mathrm{A}_{2 \mathrm{~A}} \mathrm{R}-\mathrm{A}_{2 \mathrm{~A}} \mathrm{R}$ homodimer was only disrupted by peptide $A_{2 A} R T M 6$, while when $A_{2 A} R$ was missing, $C_{1} R$ TM4 was the only peptide disturbing $C_{1} R-C B_{1} R$ homodimer formation, altogether indicating that TM6 and TM4 sequences are involved in $A_{2 A} R$ and $C_{1} R$ homodimer interfaces, respectively [59].

Once the interfering peptides are identified, they can be used to investigate GPCR complex implications in numerous physiopathological disorders. As an example, BorrotoEscuela et al. (2018) found that rat $\mathrm{A}_{2 \mathrm{~A}} \mathrm{R}$ TM5 peptide microinjection into the nucleus accumbens causes $\mathrm{A}_{2 \mathrm{~A}} \mathrm{R}-\mathrm{D}_{2} \mathrm{R}$ heteromer dissolution plus abrogation of the inhibitory effects of the $\mathrm{A}_{2 \mathrm{~A}} \mathrm{R}$ agonist CGS21680 on cocaine self-administration, therefore confirming that the $A_{2 A} R-D_{2} R$ hetero-complex can be used as a novel target to treat cocaine disorders [53].

More examples where synthetic peptides replicating TM helices involved in dimerization have been shown to be able to split GPCR complex formations are included in Table 1. The in vitro (biophysical and/or biochemical) and in vivo assays used to confirm the existence of GPCR dimers in live cells and their implication (if known) in health disorders, are also presented. 
Table 1. GPCR complexes disrupted by synthetic TM peptides.

\begin{tabular}{|c|c|c|c|c|c|}
\hline GPCR Complex & TMs Involved in Dimerization & $\begin{array}{c}\text { Synthetic TM } \\
\text { Disruptor Peptide }\end{array}$ & $\begin{array}{l}\text { In Vitro/In Vivo } \\
\text { Assays Performed }\end{array}$ & Patho-Physiological Implication & Ref. \\
\hline $\mathrm{A}_{2 \mathrm{~A}} \mathrm{R}-\mathrm{D}_{2} \mathrm{R}$ & TM4/5 interface & $\mathrm{A}_{2 \mathrm{~A}} \mathrm{R}$ TM5 & $\begin{array}{ll}\text { - } & \text { BRET } \\
\text { - } & \text { PLA } \\
\text { - } & \text { Cocaine self-administration }\end{array}$ & Cocaine use & [53] \\
\hline $\mathrm{APJR} \mathrm{OX}{ }_{1} \mathrm{R}$ & TM4/5 interface & APJ TM4, TM5 & $\begin{array}{ll}\text { - } & \text { BRET } \\
\text { - } & \text { Co-IP }\end{array}$ & - & [60] \\
\hline APJR homodimer & TM1, TM2, TM3, TM4 & TM1, TM2, TM3, TM4 & $\begin{array}{ll}- & \text { BRET } \\
- & \text { FRET } \\
\text { - } & \text { TIRFM } \\
\text { - } & \text { Co-IP }\end{array}$ & - & [61] \\
\hline $\mathrm{A}_{2 \mathrm{~A}} \mathrm{R}-\mathrm{CB}_{1} \mathrm{R}$ & TM 5/6 interface & $\begin{array}{l}\mathrm{CB}_{1} \mathrm{R} \text { TM5 TM6 } \\
\mathrm{A}_{2 \mathrm{~A}} \mathrm{R} \text { TM5 TM6 }\end{array}$ & $\begin{array}{ll}\text { - } & \text { BiFC } \\
\text { - } & \text { BRET } \\
\text { - } & \text { GODA-RET } \\
& \text { Glutamate release }\end{array}$ & Glutamate release & [59] \\
\hline$A_{1} R-A_{2 A} R$ & TM 5/6 interface & $\begin{array}{c}\mathrm{A}_{2 \mathrm{~A}} \mathrm{R} \text { TM4, TM5, TM6 } \\
\mathrm{A}_{1} \mathrm{R} \text { TM5 and TM6 }\end{array}$ & $\begin{array}{ll}\text { - } & \text { BiFC } \\
\text { - } & \text { PLA } \\
\text { - } & \text { BRET } \\
\text { - } & \text { cAMP production } \\
\text { - } & \text { DMR }\end{array}$ & $\begin{array}{l}\text { Neurodegeneration } \\
\text { Neuroinflammation }\end{array}$ & [62] \\
\hline $\mathrm{CB}_{1} \mathrm{R}-5 \mathrm{HT}_{2 \mathrm{~A}} \mathrm{R}$ & TM 5/6 interface & $\mathrm{CB}_{1} \mathrm{R}_{\mathrm{N}} \mathrm{T} 5, \mathrm{TM} 6$ & $\begin{array}{ll}\text { - } & \text { BRET } \\
\text { - } & \text { PLA } \\
\text { - } & \text { BiFC } \\
\text { - } & \text { NORT } \\
\text { - } & \text { Hot plate test }\end{array}$ & Cognitive impairment & [40] \\
\hline $\mathrm{M}_{3} \mathrm{R}$ homodimer & TM1, TM5, TM7 & TM1-TM5-TM7 & - $\quad$ BRET & - & [63] \\
\hline
\end{tabular}


Table 1. Cont.

\begin{tabular}{|c|c|c|c|c|c|}
\hline GPCR Complex & TMs Involved in Dimerization & $\begin{array}{c}\text { Synthetic TM } \\
\text { Disruptor Peptide }\end{array}$ & $\begin{array}{c}\text { In Vitro/In Vivo } \\
\text { Assays Performed }\end{array}$ & Patho-Physiological Implication & Ref. \\
\hline CCKR homodimer & TM6 & TM6 & $\begin{array}{ll}\text { - } & \text { BRET } \\
\text { - } & \text { FRET }\end{array}$ & - & [64] \\
\hline CCR5 homodimer & TM1, TM2, TM4 & TM1, TM4 & - $\quad$ FRET Calcium determination & - & [65] \\
\hline RhoR homodimer & TM1,TM2, TM4, TM5, H8 & TM1, TM2, TM4, TM5 & $\begin{array}{ll}\text { - } & \text { BRET } \\
\text { - } & \text { cAMP production }\end{array}$ & Phototransduction & [66] \\
\hline$\beta_{2} \mathrm{AR}$ homodimer & TM1, TM5, TM6, H8 & TM6 & $\begin{array}{l}\text { - } \quad \text { Adenylyl cyclase activity } \\
\text { - } \quad \text { Densitometric analyses }\end{array}$ & - & [17] \\
\hline SCTR & TM4 & TM4 & $\begin{array}{ll}\text { - } & \text { FRET } \\
\text { - } & \text { BRET }\end{array}$ & Liver diseases & [55] \\
\hline AT1aR-SCTR & $\begin{array}{l}\text { TM1/2 interface } \\
\text { TM4/4 interface }\end{array}$ & $\begin{array}{l}\text { AT1aR TM1, TM4 } \\
\text { SCTR TM2, TM4 }\end{array}$ & $\begin{array}{ll}- & \text { BRET } \\
- & \text { FRET } \\
- & \text { cAMP }\end{array}$ & Hyperosmolality-induced drinking & [54] \\
\hline $\mathrm{FZD}_{6}$ homodimer & TM4, TM5 & TM4, TM5 & $\begin{array}{ll}- & \text { FRAP } \\
\text { - } & \text { FCCS }\end{array}$ & Cancer and neurologic disorders & [67] \\
\hline MOR-DOR & MOR TM1 & MOR TM1 & $\begin{array}{ll}\text { - } & \text { Co-IP } \\
\text { - } & \text { Immunoblotting } \\
\text { - } & \text { Tail immersion }\end{array}$ & Morphine tolerance & [68] \\
\hline & \multicolumn{5}{|c|}{ 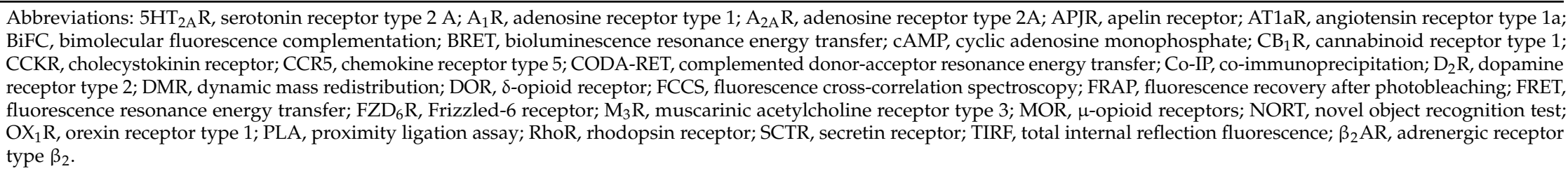 } \\
\hline
\end{tabular}




\subsection{TM Peptides: Challenges and Opportunities to Drug the Undruggable}

Despite presenting great in vitro and in vivo potential in terms of efficacy, selectivity and safety, TM peptide disruptors of GPCR complexes are viewed as undesirable leads for therapeutic application due to their peptide-intrinsic poor pharmacokinetics, including low water solubility, high susceptibility to proteases, poor membrane permeability (including challenging physiological barriers such as the BBB), rapid clearance and immunogenicity [69]. These caveats notwithstanding, an array of peptide engineering strategies have been used over the years to improve druggability (see next paragraph and below) and can be also implemented in this case to develop optimized versions of GPCR complexdisrupting TM peptides and explore their therapeutic applications.

The first useful item in the toolbox is trimming off some $\mathrm{N}$-terminal or $\mathrm{C}$-terminal residues until a minimally active primary structure can be established (Figure 2A). This reductionistic approach is particularly efficacious in the case of TM peptides since, by removing (almost invariably hydrophobic) residues from the cognate TM sequence, water solubility is improved [70-72], while synthesis time and costs are considerably reduced. Another strategy to improve peptide solubility is PEGylation, i.e., attaching several polyethylene glycol (PEG) units to the peptide lead structure (Figure 2B). PEG moieties, apart from being highly hydrophilic, are also good non-immunogenic spacers able to shield the peptide from proteolytic enzymes $[73,74]$. Additionally, related to this issue, the replacement of natural L- by non-natural D-amino acids is a common manoeuvre to improve peptide stability towards proteases in the digestive tract (e.g., trypsin), plasma and other biological fluids (Figure 2C). Furthermore, non-natural amino acids can enhance target affinity and selectivity by the induction or stabilization of secondary structure motifs ( $\alpha$-helices, $\beta$-sheets, $\beta$-turns) $[75,76]$. Along similar lines, the so-called retro-enantio approach can likewise give rise to peptides fully resistant to natural proteases. In a retro-enantio peptide both amino acid sequence and residue chirality are reversed relative to the parent structure, but despite these substantial changes the orientation of the side chains is preserved, hence a resemblance in overall shape (Figure 2D), while the inverted chirality curbs protease degradation, enhancing half-life and thus the potential as a new drug lead [77]. Moreover, the retro-enantio analogue tends to be less immunogenic than the cognate sequence [78]. Lastly, cyclization (head-to-tail (Figure 2E), side-chain-to-tail, side-chain-to-side-chain), including disulfide bond formation from native or (more frequently) engineered cysteine residues, is another quite valuable tool in the box that is regularly shown to reinforce serum stability [79]. Low membrane permeability, poor cellular uptake and inadequate homing specificity [80] are well-recognized snags that seriously jeopardize the success of peptide drugs. In this regard, a variety of drug carriers [81,82], with cell-penetrating peptides (CPPs) as a preeminent, successful example, have emerged as safe and efficient strategies to improve bioavailability. CPPs are a family of short peptide vectors with a remarkable inbuilt ability to traverse membranes, including important physiological hurdles such as the blood-brain or the skin barriers or the intestinal and nasal mucosae. Acting as drug delivery vectors (Figure 2B), CPPs can deliver into cells a plethora of payloads with therapeutic or diagnostic purposes, overcoming pharmacokinetic limitations and poor access to difficult areas, such as the central nervous system [80]. In sum, CPPs have become a powerful tool to address one of the main bottlenecks in drug development, namely the successful delivery of active compounds to target sites [80]. Moreover, in the specific case of GPCR complexes, CPPs can also determine the trajectory of the peptide disruptor into the membrane [80]. Peptide backbone modification is also an important and widely used approach to improve bioavailability $[83,84]$. Still another strategy to increase target affinity and cell uptake, as well as to protect against proteolytic degradation, involves stapling, whereby a synthetic brace (staple) introduced between two preestablished sites in the sequence helps to lock the peptide into a specific secondary structure (Figure $2 \mathrm{~F}$ ), thus reducing conformational entropy [85-87]. In the context of $\mathrm{CB}_{1} \mathrm{R}-5 \mathrm{HT}_{2 \mathrm{~A}} \mathrm{R}$ complex disruption, the stapling approach has been recently applied [88], with preservation of in vitro GPCR oligomer disrupting activity along with improved proteolytic resistance. 

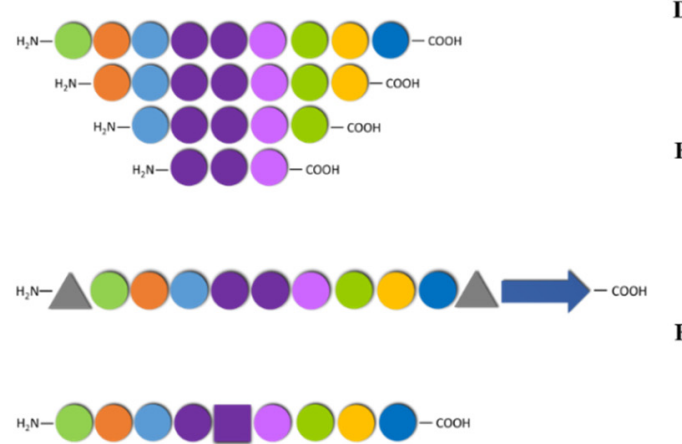

D

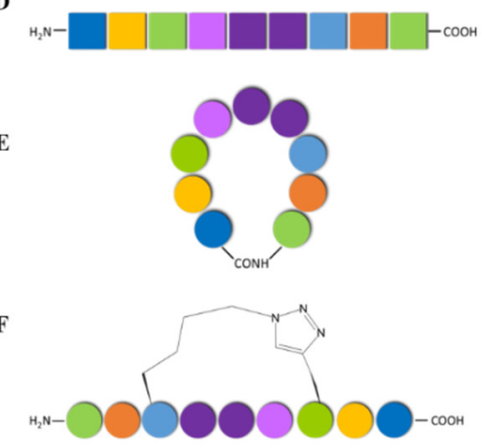

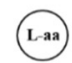
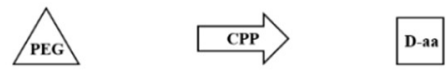

Figure 2. Useful synthetic strategies towards drug-like peptide design: (A) Peptide truncation at both $\mathrm{N}$ - and C- termini to identify the shortest active amino acid sequence; (B) peptide conjugation to PEG and/or CPP to enhance solubility and cell membrane permeation; $(\mathrm{C})$ replacement of L- with Damino acid to improve proteolytic stability; (D) retro-enantio approach to achieve a protease-resistant peptide with overall shape resemblance; (E) head-to-tail cyclization to increase half-life of peptides; (F) Stapling to constrain the peptide into a specific conformation.

Even though the resources in the peptide engineering toolbox just mentioned have allowed overcoming many of the factors limiting the therapeutic use of natural peptides with moderate success, for GPCR complex-disrupting peptides in particular, the goal of turning a canonical TM sequence into a viable drug lead may still entail a hazardous journey fraught with formidable obstacles. Even so, the latest literature reveals a slowly growing body of reports, including recent work from our group, where some of the aforementioned strategies are creatively applied to improve the druggability of GPCR complex-disrupting peptides. Two such accounts, dealing with the medical use of cannabinoids to fight pain and CNS disorder exploration and treatment, are discussed at some length below, illustrating the design and structural optimization process where TM peptides involved in GPCR dimer interfaces are developed into promising leads in two therapeutic areas with still unmet needs.

\subsection{TM Peptides Restricting $C B_{1} R-5 H T_{2 A} R$ Dimer for Cannabinoid Management in Pain Therapy}

While cannabinoid-based therapy has proven effective in alleviating chronic pain [89-91], its psychotropic side effects such as memory loss, disorientation or dizziness are major obstacles in attempts to deploy cannabinoids as analgesics [92-95]. To this day, cannabinoids, both synthetic and naturally occurring, remain at the center of social, legal and medical debates concerning their therapeutic value, while the need for novel pain-alleviating medicines whose beneficial effects outweigh adverse ones is quite obvious in everyday clinical practice.

Various strategies have been investigated to minimize the unwanted outcomes of long-lasting cannabinoid exposure in patients undergoing cannabis-based therapies, so far to little avail. In line with this goal and with the topic of this review, we will now discuss work from our group and allied laboratories exploring the possibility of dissociating $\Delta^{9}$-tetrahydrocannabinol's (THC) beneficial effects from its detrimental effects by using an optimized TM peptide disruptor to alter the $\mathrm{CB}_{1} \mathrm{R}-5 \mathrm{HT}_{2 \mathrm{~A}} \mathrm{R}$ complex, i.e., the heterodimer formed by the cannabinoid $\mathrm{CB}_{1}$ and serotonin $5 \mathrm{HT}_{2 \mathrm{~A}}$ receptors that is responsible for the undesirable cognitive impairment [40].

In order to identify the functional properties of the $\mathrm{CB}_{1} \mathrm{R}-5 \mathrm{HT} \mathrm{T}_{2 \mathrm{~A}} \mathrm{R}$ heterodimer, we first used synthetic peptides reproducing the entire amino acid sequences of the $C_{1} R$ TM5 and TM6 helices, fused to a cell-penetrating sequence derived from HIV-Tat, to disturb the formation of the heteromer [96]. These peptides were confirmed to be able 
to interfere with the $\mathrm{CB}_{1} \mathrm{R}-5 \mathrm{HT}_{2 \mathrm{~A}} \mathrm{R}$ complex, both in vitro (BiFC, cAMP assay and pERK1/2 signalling) and in vivo (hot plate test and novel object recognition tests, after ICV administration in mice), allowing the selective activation of $\mathrm{CB}_{1} \mathrm{R}$ by THC [96]. However, their poor pharmacological profiles (i.e., long size, rapid proteolytic digestion, no trans-BBB permeability) were major drawbacks vis-á-vis any medical application. Therefore, with the goal in mind of preserving analgesic properties while minimizing cognitive side effects, our next step was to improve TM5 and TM6 peptide druggability by a combined effort aimed at reducing toxicity, prolonging serum half-life, avoiding immunogenicity, achieving BBB permeability and generally enhancing bioavailability, with oral activity as the final goal [96] (Figure 3).

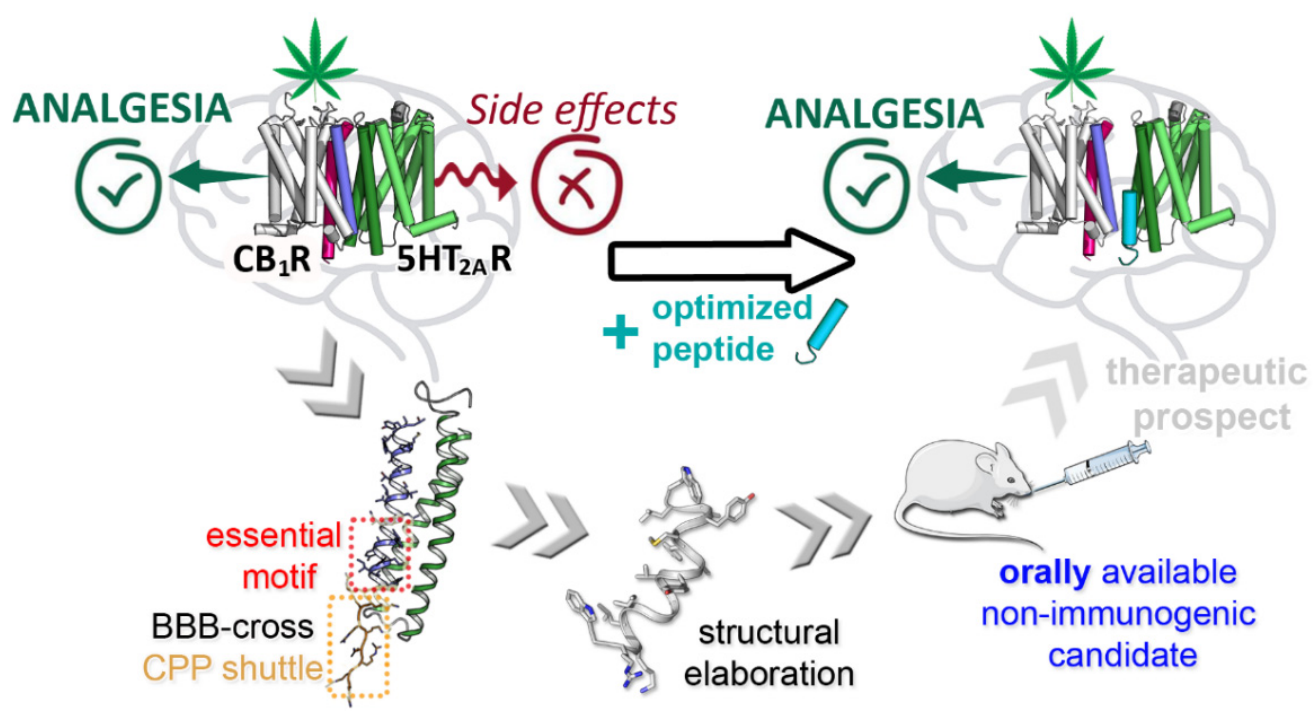

Figure 3. Development of a downsized, protease-resistant, orally available peptide compound, fused to an enhanced BBB-crossing CPP, which restricts the $C_{1} \mathrm{R}-5 \mathrm{HT}_{2 \mathrm{~A}} \mathrm{R}$ heterodimer formation correlated to THC's unwanted effects. (Reproduced with permission from [96]. American Chemical Society, 2021. Copyright (C) 2021 American Chemical Society, https://pubs.acs.org/doi/10.1021/ acs.jmedchem.1c00484 (accessed on 27 December 2021). Further permissions related to the material excerpted should be directed to the American Chemical Society).

After in silico identification of hotspots (i.e., close contact residues) in the $\mathrm{CB}_{1} \mathrm{R}$ $5 \mathrm{HT}_{2 \mathrm{~A}} \mathrm{R}$ heterodimer interfaces, streamlined versions of the TM5 and TM6 peptides, i.e., containing mainly those amino acid residues predicted as involved in the interaction domain, were designed, synthesized and assayed, again juxtaposed to a CPP shuttle sequence (several size-optimized options tested). The results indicate that: (i) the downsized versions were as efficient as the original TM sequences in disrupting the $C_{1} R-5 H_{2} T_{2} R$ heteromer, and (ii) the previously used HIV-Tat CPP motif could be replaced, without loss in disruptive capacity, by a BBB shuttle peptide (BBBsP) sequence that ensured bioavailability of the novel analogs into their brain target [96].

In a last optimization round, candidates with reversed (i.e., non-natural D-residue) chirality were generated as the retro-enantio versions of the previous, shortened interfering peptides, again fused to a BBBsP motif also made up of D-residues. As mentioned earlier, by virtue of the retro-enantio approach the spatial orientation of the TM peptide side chains, hence the global shape, roughly resembles the canonical versions, and in tune with this, remains able to disturb the $\mathrm{CB}_{1} \mathrm{R}-5 \mathrm{HT}_{2 \mathrm{~A}} \mathrm{R}$ heterodimer (in the BiFC assay). In addition, the BBBsP tag ensured efficient crossing of an in vitro BBB model and, given the all-D configuration, the peptide turned out to be highly resistant to serum proteases [96].

The last stage in our approach was evaluation in vivo: the two best-performing candidates were given intravenously to mice, co-administered with THC. While analgesic effects were observed for both peptides, only one of them was able to prevent THC-induced 
cognitive impairment. This peptide, wliymyayvaGilkrw (lower case one-letter notation for D-residues), was additionally shown to be orally available and non-immunogenic and is hence regarded as a highly promising lead in therapeutic approaches involving cannabinoid pain management without undesirable cognitive side effects [96].

\subsection{TM Peptide Restricting $A_{2 A} R-A_{2 A} R$ Dimer for CNS Disorders}

Several functional G-protein heterodimers (Table 2, entries 1-7) and heterotrimers (Table 2, entries 8-10) with other GPCRs have been observed and described for the adenosine $A_{2 A}$ receptor $\left(A_{2 A} R\right)$, playing significant roles in neurodegenerative diseases or drug abuse. Apart from heteromerization, $\mathrm{A}_{2 \mathrm{~A}} \mathrm{R}$ homodimerization is well-recognized and raising attention as $A_{2 A} R-A_{2 A} R$ homodimer inhibition has been recently reported to be involved in CNS disorders [97].

Table 2. $\mathrm{A}_{2 \mathrm{~A}} \mathrm{R}$ complexes with other GPCRs and their implications.

\begin{tabular}{|c|c|c|c|}
\hline Heteromer & Ligand & Implication & Ref. \\
\hline $\mathrm{A}_{1} \mathrm{R}-\mathrm{A}_{2 \mathrm{~A}} \mathrm{R}$ & Caffein $\left(\mathrm{A}_{1} \mathrm{R}, \mathrm{A}_{2} \mathrm{R}\right.$ antagonist $)$ & Drug tolerance & [98] \\
\hline $\mathrm{A}_{2 \mathrm{~A}} \mathrm{R}-\mathrm{D}_{2} \mathrm{R}$ & $\mathrm{A}_{2 \mathrm{~A}} \mathrm{R}$ antagonists, $\mathrm{D}_{2} \mathrm{R}$ agonists & $\begin{array}{c}\text { Parkinson's disease, } \\
\text { schizophrenia, drug addiction }\end{array}$ & {$[99,100]$} \\
\hline $\mathrm{D}_{3} \mathrm{R}-\mathrm{A}_{2 \mathrm{~A}} \mathrm{R}$ & CGS-21680 ( $\mathrm{A}_{2 \mathrm{~A}} \mathrm{R}$ agonist) & Schizophrenia & [101] \\
\hline $\mathrm{CB}_{1} \mathrm{R}-\mathrm{A}_{2 \mathrm{~A}} \mathrm{R}$ & CBD $\left(\mathrm{CB}_{1} \mathrm{R}\right.$ agonist $)$ & Cognitive impairment & {$[102,103]$} \\
\hline $\mathrm{A}_{2 \mathrm{~A}} \mathrm{R}-\mathrm{mGlu}{ }_{5} \mathrm{R}$ & CHPG (mGluR5 agonist) & Parkinson's disease & [23] \\
\hline $\mathrm{A}_{2 \mathrm{~A}} \mathrm{R}-\mathrm{H}_{3} \mathrm{R}$ & $\mathrm{RAMH}\left(\mathrm{H}_{3} \mathrm{R}\right.$ agonist $)$ & $\begin{array}{l}\text { Autism, obsessive and } \\
\text { compulsive disorder }\end{array}$ & [104] \\
\hline $\mathrm{A}_{2 \mathrm{~A}} \mathrm{R}-5 \mathrm{HT}_{1 \mathrm{~A}} \mathrm{R}$ & $\begin{array}{c}\text { CGS 21,680 }\left(\mathrm{A}_{2 \mathrm{~A}} \mathrm{R} \text { agonist), } 8-\mathrm{OH}-\mathrm{DPAT}\left(5 \mathrm{HT}_{1 \mathrm{~A}} \mathrm{R}\right.\right. \\
\text { agonist), } \mathrm{SCH} 58,216\left(\mathrm{~A}_{2 \mathrm{~A}} \mathrm{R} \text { antagonist }\right) \\
\text { methysergide }\left(5 \mathrm{HT}_{1 \mathrm{~A}} \mathrm{R} \text { antagonist }\right)\end{array}$ & Dyskinesia & [105] \\
\hline $\mathrm{A}_{2 \mathrm{~A}} \mathrm{R}-\mathrm{D}_{2} \mathrm{R}-\mathrm{mGlu}{ }_{5} \mathrm{R}$ & $\begin{array}{c}\mathrm{A}_{2 \mathrm{~A}} \mathrm{R} \text { agonists, } \mathrm{A}_{2 \mathrm{~A}} \mathrm{R} \text { antagonists, } \mathrm{D}_{2} \mathrm{R} \text { agonists, } \\
\mathrm{D}_{2} \mathrm{R} \text { antagonists, } m \text { Glu }{ }_{5} \mathrm{R} \text { agonists }\end{array}$ & $\begin{array}{l}\text { Psychosis, Parkinson's } \\
\text { disease, drug abuse }\end{array}$ & [106] \\
\hline $\mathrm{CB}_{1} \mathrm{R}-\mathrm{A}_{2 \mathrm{~A}} \mathrm{R}-\mathrm{D}_{2} \mathrm{R}$ & TBD & Endocannabinoid modulation & [107] \\
\hline $\mathrm{A}_{2 \mathrm{~A}} \mathrm{R}-\mathrm{D}_{2} \mathrm{R}-\mathrm{NMDAR}$ & $\alpha$-synuclein & $\begin{array}{l}\text { Neurodegeneration, } \\
\text { neuroinflammation }\end{array}$ & [108] \\
\hline
\end{tabular}

Abbreviations: $5 \mathrm{HT}_{1 \mathrm{~A}} \mathrm{R}$, serotonin receptor type $1 \mathrm{~A} ; 5 \mathrm{HT}_{2 \mathrm{~A}} \mathrm{R}$, serotonin receptor type $2 \mathrm{~A} ; \mathrm{A}_{1} \mathrm{R}$, adenosine receptor type 1; 8-OH-DPAT, 8-Hydroxy-2-(di-n-propylamino)tetralin; $\mathrm{A}_{2 \mathrm{~A}} \mathrm{R}$, adenosine receptor type 2A; $\mathrm{CBD}$, cannabidiol; $\mathrm{CB}_{1} \mathrm{R}$, cannabinoid receptor type 1; CHPG, $(\mathrm{R}, \mathrm{S})-2$-chloro-5-hydroxyphenylglycine; CG6-21680, 4-[2-[[6amino-9(N-ethyl-beta-d-ribofuranuronaminoamidosyl)-9H-purin-2-yl]amino]ethyl]benzenepropanoic acid; $\mathrm{D}_{2} \mathrm{R}$, dopamine receptor type $2 ; \mathrm{D}_{3} \mathrm{R}$, dopamine receptor type $3 ; \mathrm{mGlu}_{5} \mathrm{R}$, metabotropic glutamate receptor type $5 ; \mathrm{H}_{3} \mathrm{R}$, histamine receptor type 3; NMDAR; 'N-metil-D-aspartate receptor; RAMH, (R)-(alpha)-(-)-methylhistamine dihydrobromide; SCH 58216, [5-amino-7-(2-phenylethyl)-2-(2-furyl)-pyrazolo [4,3-e]-1,2,4-triazolo[1.5-c]pyrimidine]; TBD, to be determined.

One strategy to explore $A_{2 A} R-A_{2 A} R$ homodimer expression and its impact on brain disorders would consist, as in previous accounts above, in interfering in their formation by means of synthetic peptides replicating TM domains involved in helix-helix interactions. Thus, our laboratory recently ventured to assess $A_{2 A} R-A_{2 A} R$ homodimer functionality using a peptide comprising the $\mathrm{A}_{2 \mathrm{~A}} \mathrm{R}$ TM5 sequence, involved in the homodimer interface, fused to a linear HIV-Tat (47-57) CPP. Unfortunately, the outcome was unclear due to the fast in vivo degradation of the peptide.

Different strategies to boost CPP protease resistance while preserving cell penetration efficiency have been developed [109]. One noteworthy approach is that afforded by cyclic versions of CPPs (CCPPs for short) such as cyclo Tat [110] or CPP12 [111]. These novel platforms have shown superior translocation ability over the linear versions and, importantly, a higher imperviousness to protease degradation. Based on such precedents, we set out to develop a construct where the TM5 peptide disruptor was linked to a cyclic Tat-like construct (Figure 4), with a view of ensuring an extended lifespan that might prove 
useful for future in vivo $\mathrm{A}_{2 \mathrm{~A}} \mathrm{R}-\mathrm{A}_{2 \mathrm{~A}} \mathrm{R}$ homodimer studies. The hypothesis proved correct, and the CCPP afforded higher $\mathrm{A}_{\mathrm{A} 2} \mathrm{R}-\mathrm{A}_{2 \mathrm{~A}} \mathrm{R}$ disrupting capability than the linear HIV-Tat counterpart. Moreover, by including non-natural amino acids, the desired high proteolytic stability under physiological conditions was also achieved [97].

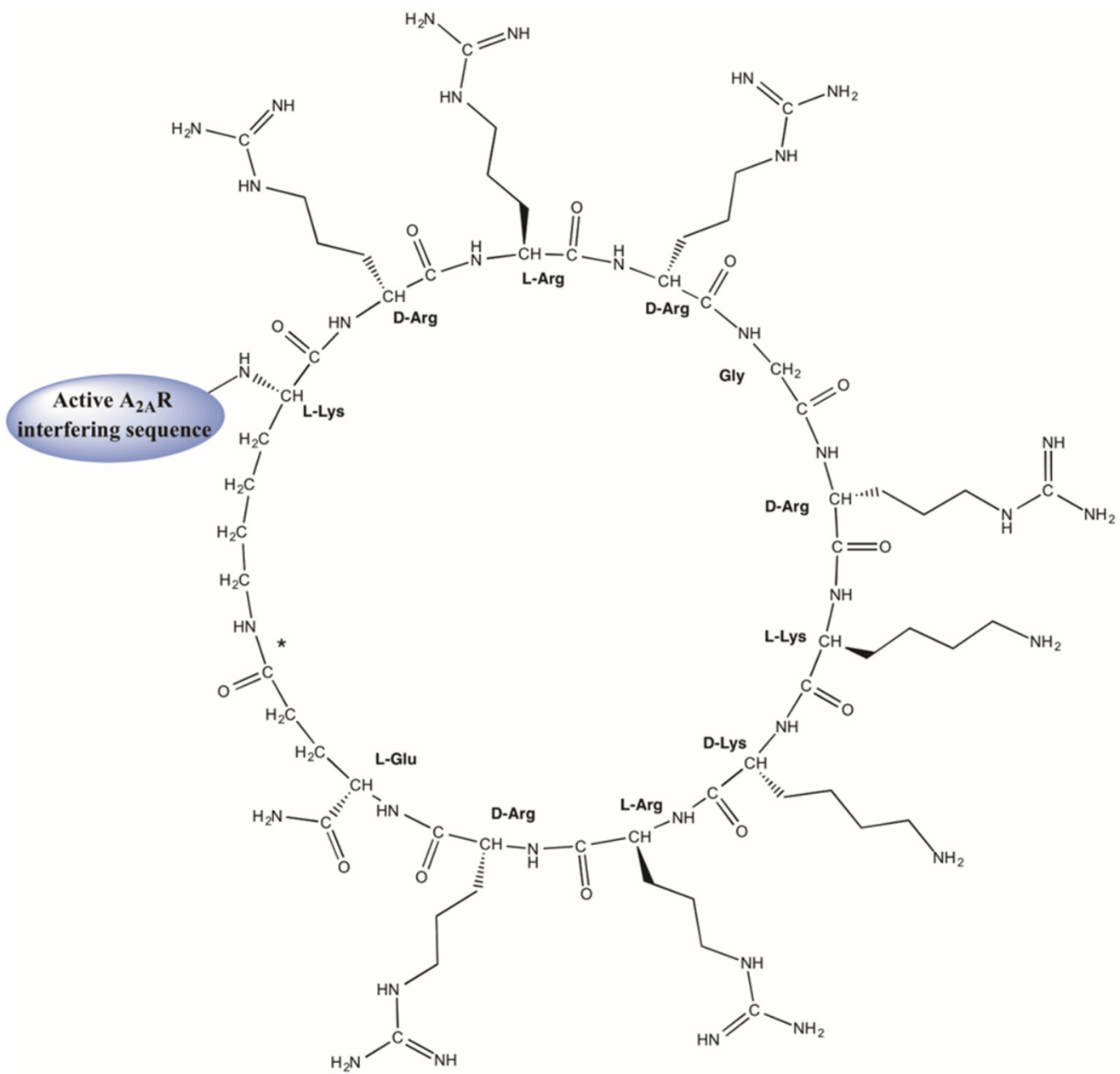

Figure 4. Design of an efficient $\mathrm{A}_{2 \mathrm{~A}} \mathrm{R}-\mathrm{A}_{2 \mathrm{~A}} \mathrm{R}$ complex disruptor by combining a homodimerizationblocking sequence with a modified CCPP with improved pharmacokinetics properties (Figure adapted from [97]. MDPI, 2019). The Tat-like construct combines both L- and D-amino acids, and a side-chain-to-side-chain cyclization between the $\varepsilon$-amino group of the $\mathrm{N}$-terminal Lys and the $\gamma$-carboxyl of C-terminal Glu (marked with an asterisk).

\section{Conclusions}

$\mathrm{G}$ protein-coupled receptors are preeminent among drug targets and, given the intensive research efforts devoted to them, are arguably likely to remain valuable sources of future pharmaceutical leads with important therapeutic indications. In this context, the emerging evidence of naturally existing GPCR oligomers has upended the conventional wisdom of the GPCR monomer as functional unit, opening up new horizons for pharmacological intervention. However, in contrast to well-studied GPCR monomer transduction, the mechanisms of GPCR oligomerization and, more importantly, their implication in health or disease, remain in most cases only partially elucidated and need to be studied further.

Several approaches have been made to gain insights into the functional relevance of GPCR oligomerization. For example, bivalent ligands that simultaneously bind the two physically interacting GPCRs orthosteric sites can be used as valuable pharmacological tools to study the quaternary structure of receptor dimers. Alternatively, mutant receptors that do not dimerize can be applied to probe the role of oligomers in the modulation of 
signal transduction. In this scenario, GPCR complex disruption by peptides reproducing TM sequences involved in dimer interfaces is increasingly recognized as a fruitful method for GPCR oligomer functional exploration, thus holding significant promise for the rational design of new GPCR-homing peptide drugs.

Despite their undisputed potential in medicinal applications, naturally occurring peptides have long been singled out as therapeutically problematic for intrinsic weaknesses such as low bioavailability and/or short in vivo half-life. To redress these shortcomings, an extensive array of structural modifications including $\mathrm{C}$ - or $\mathrm{N}$-terminal truncation, use of non-natural amino acids, PEGylation or different cyclization tactics, to name just a few, have been successfully deployed over the years to fulfil the switch from natural (vulnerable) to engineered (drug-like), best-performing peptide leads. In the specific realm of TM peptides targeting GPCR oligomers, increasing research shows how, contrary to deeply rooted prejudice, educated structural elaboration of an initially naive sequence can enact its evolution into a full-fledged medicinal peptide entity. The first example of such transition shows that the analgesic properties of cannabinoids can be exploited while keeping their adverse side reactions (i.e., psychoactive effects and cognitive impairment) at bay by co-administration with a novel optimized $\mathrm{CB}_{1} \mathrm{R}-5 \mathrm{HT}_{2 \mathrm{~A}} \mathrm{R}$ heterodimer-disrupting peptide. Such an approach has predictable potential in alleviating the plight of patients undergoing chronic pain medication. In this study, inclusion in the late-stage candidate of a substantially engineered CPP tag has turned out to be decisive, by endowing the peptide with $\mathrm{BBB}$-crossing properties and hence access to brain cells where it can productively disrupt the $\mathrm{CB}_{1} \mathrm{R}-5 \mathrm{HT}_{2 \mathrm{~A}} \mathrm{R}$ heterodimer. Similarly, an $\mathrm{A}_{2 \mathrm{~A}} \mathrm{R}$ homodimer-disrupting construct, efficiently delivered by a protease-resistant cyclic CPP, was designed and produced for in vivo studies on the $A_{2 A} R-A_{2 A} R$ homodimer implication in CNS disorders, including schizophrenia and Parkinson's disease. Understanding its CNS delivery may pave the way to eventually harnessing some of the most challenging problems faced in the treatment of neurodegeneration. These encouraging developments are to be viewed as the first fruits in the quest for GPCR complex-disrupting agents, a field holding undoubtable promise for therapeutic application but where much work remains to be done.

Author Contributions: Writing original draft preparation, M.G.; writing-review and editing, M.G., S.D., D.A.; supervision, S.D. and D.A. All authors have read and agreed to the published version of the manuscript.

Funding: Financial support from the Spanish Ministry of Economy and Innovation (AGL201784097-C2-2-R, FEDER funds) and from La Caixa Banking Foundation (HR17-00409 and CI18-0045) is acknowledged.

Institutional Review Board Statement: Not applicable.

Informed Consent Statement: Not applicable.

Acknowledgments: The Department of Experimental and Health Sciences at UPF is a member of the "María de Maeztu" Program for Units of Excellence in R\&D (CEX2018-000792-M) from the Spanish Ministry of Economy and Competitiveness (MINECO).

Conflicts of Interest: The authors declare no conflict of interest.

\section{References}

1. Pierce, K.L.; Premont, R.T.; Lefkowitz, R.J. Seven-transmembrane receptors. Nat. Rev. Mol. Cell Biol. 2002, 3, 639-650. [CrossRef] [PubMed]

2. Lefkowitz, R.J. Historical review: A brief history and personal retrospective of seven-transmembrane receptors. Trends Pharmacol. Sci. 2004, 25, 413-422. [CrossRef]

3. Limbird, L.E.; Meyts, P.D.; Lefkowitz, R.J. Beta-adrenergic receptors: Evidence for negative cooperativity. Biochem. Biophys. Res. Commun. 1975, 64, 1160-1168. [CrossRef]

4. Wettschureck, N.; Offermanns, S. Mammalian G proteins and their cell type specific functions. Physiol. Rev. 2005, 85, 1159-1204. [CrossRef] [PubMed]

5. Attwood, T.K.; Findlay, J.B. Fingerprinting G-protein-coupled receptors. Protein Eng. 1994, 7, 195-203. [CrossRef]

6. Tuteja, N. Signaling through G protein coupled receptors. Plant Signal. Behav. 2009, 4, 942-947. [CrossRef] [PubMed] 
7. Wacker, D.; Stevens, R.C.; Roth, B.L. How Ligands Illuminate GPCR Molecular Pharmacology. Cell 2017, 170, 414-427. [CrossRef]

8. Ferré, S.; Bonaventura, J.; Tomasi, D.; Navarro, G.; Moreno, E.; Cortés, A.; Lluís, C.; Casadó, V.; Volkow, N.D. Allosteric mechanisms within the adenosine A2A-dopamine D2 receptor heterotetramer. Neuropharmacology 2016, 104, 154-160. [CrossRef] [PubMed]

9. Cook, J.L. G protein-coupled receptors as disease targets: Emerging paradigms. Ochsner J. 2010, 10, 2-7.

10. Sriram, K.; Insel, P.A. G Protein-Coupled Receptors as Targets for Approved Drugs: How Many Targets and How Many Drugs? Mol. Pharmacol. 2018, 93, 251-258. [CrossRef]

11. Jacobson, K.A. New paradigms in GPCR drug discovery. Biochem. Pharmacol. 2015, 98, 541-555. [CrossRef] [PubMed]

12. Nieto Gutierrez, A.; McDonald, P.H. GPCRs: Emerging anti-cancer drug targets. Cell. Signal. 2018, 41, 65-74. [CrossRef] [PubMed]

13. Hauser, A.S.; Chavali, S.; Masuho, I.; Jahn, L.J.; Martemyanov, K.A.; Gloriam, D.E.; Babu, M.M. Pharmacogenomics of GPCR Drug Targets. Cell 2018, 172, 41-54.e19. [CrossRef]

14. Glukhova, A.; Draper-Joyce, C.J.; Sunahara, R.K.; Christopoulos, A.; Wootten, D.; Sexton, P.M. Rules of Engagement: GPCRs and G Proteins. ACS Pharmacol. Transl. Sci. 2018, 1, 73-83. [CrossRef]

15. Milligan, G.; Ward, R.J.; Marsango, S. GPCR homo-oligomerization. Curr. Opin. Cell Biol. 2019, 57, 40-47. [CrossRef]

16. Fuxe, K.; Borroto-Escuela, D.O.; Marcellino, D.; Romero-Fernandez, W.; Frankowska, M.; Guidolin, D.; Filip, M.; Ferraro, L.; Woods, A.S.; Tarakanov, A.; et al. GPCR heteromers and their allosteric receptor-receptor interactions. Curr. Med. Chem. 2012, 19, 356-363. [CrossRef]

17. Hebert, T.E.; Moffett, S.; Morello, J.P.; Loisel, T.P.; Bichet, D.G.; Barret, C.; Bouvier, M. A peptide derived from a beta2-adrenergic receptor transmembrane domain inhibits both receptor dimerization and activation. J. Biol. Chem. 1996, 271, 16384-16392. [CrossRef] [PubMed]

18. Fredriksson, R.; Lagerström, M.C.; Lundin, L.-G.; Schiöth, H.B. The G-protein-coupled receptors in the human genome form five main families. Phylogenetic analysis, paralogon groups, and fingerprints. Mol. Pharmacol. 2003, 63, 1256-1272. [CrossRef]

19. Li, X.; Zhou, M.; Huang, W.; Yang, H. N-glycosylation of the $\beta(2)$ adrenergic receptor regulates receptor function by modulating dimerization. FEBS J. 2017, 284, 2004-2018. [CrossRef]

20. Bagher, A.M.; Young, A.P.; Laprairie, R.B.; Toguri, J.T.; Kelly, M.E.M.; Denovan-Wright, E.M. Heteromer formation between cannabinoid type 1 and dopamine type 2 receptors is altered by combination cannabinoid and antipsychotic treatments. $J$. Neurosci. Res. 2020, 98, 2496-2509. [CrossRef]

21. Ferré, S.; Ciruela, F. Functional and Neuroprotective Role of Striatal Adenosine A(2A) Receptor Heterotetramers. J. Caffeine Adenosine Res. 2019, 9, 89-97. [CrossRef] [PubMed]

22. Bono, F.; Mutti, V.; Fiorentini, C.; Missale, C. Dopamine D3 Receptor Heteromerization: Implications for Neuroplasticity and Neuroprotection. Biomolecules 2020, 10, 1016. [CrossRef]

23. Borroto-Escuela, D.O.; Tarakanov, A.O.; Brito, I.; Fuxe, K. Glutamate heteroreceptor complexes in the brain. Pharmacol. Rep. 2018, 70, 936-950. [CrossRef]

24. Bontempi, L.; Savoia, P.; Bono, F.; Fiorentini, C.; Missale, C. Dopamine D3 and acetylcholine nicotinic receptor heteromerization in midbrain dopamine neurons: Relevance for neuroplasticity. Eur. Neuropsychopharmacol. J. Eur. Coll. Neuropsychopharmacol. 2017, 27, 313-324. [CrossRef]

25. Guitart, X.; Navarro, G.; Moreno, E.; Yano, H.; Cai, N.-S.; Sánchez-Soto, M.; Kumar-Barodia, S.; Naidu, Y.T.; Mallol, J.; Cortés, A.; et al. Functional selectivity of allosteric interactions within G protein-coupled receptor oligomers: The dopamine D1-D3 receptor heterotetramer. Mol. Pharmacol. 2014, 86, 417-429. [CrossRef] [PubMed]

26. Cai, N.-S.; Quiroz, C.; Bonaventura, J.; Bonifazi, A.; Cole, T.O.; Purks, J.; Billing, A.S.; Massey, E.; Wagner, M.; Wish, E.D.; et al. Opioid-galanin receptor heteromers mediate the dopaminergic effects of opioids. J. Clin. Investig. 2019, 129, 2730-2744. [CrossRef]

27. Wang, J.; Hua, T.; Liu, Z.-J. Structural features of activated GPCR signaling complexes. Curr. Opin. Struct. Biol. 2020, 63, 82-89. [CrossRef] [PubMed]

28. Borroto-Escuela, D.O.; Ferraro, L.; Narvaez, M.; Tanganelli, S.; Beggiato, S.; Liu, F.; Rivera, A.; Fuxe, K. Multiple AdenosineDopamine (A2A-D2 Like) Heteroreceptor Complexes in the Brain and Their Role in Schizophrenia. Cells 2020, 9, 1077. [CrossRef]

29. Perreault, M.L.; Hasbi, A.; O'Dowd, B.F.; George, S.R. Heteromeric dopamine receptor signaling complexes: Emerging neurobiology and disease relevance. Neuropsychopharmacology 2014, 39, 156-168. [CrossRef] [PubMed]

30. Farran, B. An update on the physiological and therapeutic relevance of GPCR oligomers. Pharmacol. Res. 2017, 117, 303-327. [CrossRef]

31. Jordan, B.A.; Devi, L.A. G-protein-coupled receptor heterodimerization modulates receptor function. Nature 1999, 399, 697-700. [CrossRef] [PubMed]

32. Xue, L.; Sun, Q.; Zhao, H.; Rovira, X.; Gai, S.; He, Q.; Pin, J.-P.; Liu, J.; Rondard, P. Rearrangement of the transmembrane domain interfaces associated with the activation of a GPCR hetero-oligomer. Nat. Commun. 2019, 10, 2765. [CrossRef]

33. Kasai, R.S.; Ito, S.V.; Awane, R.M.; Fujiwara, T.K.; Kusumi, A. The Class-A GPCR Dopamine D2 Receptor Forms Transient Dimers Stabilized by Agonists: Detection by Single-Molecule Tracking. Cell Biochem. Biophys. 2018, 76, 29-37. [CrossRef] [PubMed]

34. Tabor, A.; Weisenburger, S.; Banerjee, A.; Purkayastha, N.; Kaindl, J.M.; Hübner, H.; Wei, L.; Grömer, T.W.; Kornhuber, J.; Tschammer, N.; et al. Visualization and ligand-induced modulation of dopamine receptor dimerization at the single molecule level. Sci. Rep. 2016, 6, 33233. [CrossRef] 
35. Aslanoglou, D.; Alvarez-Curto, E.; Marsango, S.; Milligan, G. Distinct Agonist Regulation of Muscarinic Acetylcholine M2M3 Heteromers and Their Corresponding Homomers. J. Biol. Chem. 2015, 290, 14785-14796. [CrossRef]

36. Gao, Y.; Westfield, G.; Erickson, J.W.; Cerione, R.A.; Skiniotis, G.; Ramachandran, S. Isolation and structure-function characterization of a signaling-active rhodopsin-G protein complex. J. Biol. Chem. 2017, 292, 14280-14289. [CrossRef] [PubMed]

37. Navarro, G.; Cordomi, A.; Zelman-Femiak, M.; Brugarolas, M.; Moreno, E.; Aguinaga, D.; Perez-Benito, L.; Cortes, A.; Casado, V.; Mallol, J.; et al. Quaternary structure of a G-protein-coupled receptor heterotetramer in complex with Gi and Gs. BMC Biol. 2016, 14, 26. [CrossRef]

38. Cordomí, A.; Navarro, G.; Aymerich, M.S.; Franco, R. Structures for G-Protein-Coupled Receptor Tetramers in Complex with G Proteins. Trends Biochem. Sci. 2015, 40, 548-551. [CrossRef]

39. Deganutti, G.; Salmaso, V.; Moro, S. Could Adenosine Recognize its Receptors with a Stoichiometry Other than 1:1? Mol. Inform. 2018, 37, e1800009. [CrossRef]

40. Vinals, X.; Moreno, E.; Lanfumey, L.; Cordomi, A.; Pastor, A.; de La Torre, R.; Gasperini, P.; Navarro, G.; Howell, L.A.; Pardo, L.; et al. Cognitive Impairment Induced by Delta9-tetrahydrocannabinol Occurs through Heteromers between Cannabinoid CB1 and Serotonin 5-HT2A Receptors. PLoS Biol. 2015, 13, e1002194. [CrossRef]

41. Rashid, A.J.; So, C.H.; Kong, M.M.C.; Furtak, T.; El-Ghundi, M.; Cheng, R.; O’Dowd, B.F.; George, S.R. D1-D2 dopamine receptor heterooligomers with unique pharmacology are coupled to rapid activation of Gq/11 in the striatum. Proc. Natl. Acad. Sci. USA 2007, 104, 654-659. [CrossRef]

42. Bellot, M.; Galandrin, S.; Boularan, C.; Matthies, H.J.; Despas, F.; Denis, C.; Javitch, J.; Mazères, S.; Sanni, S.J.; Pons, V.; et al. Dual agonist occupancy of AT1-R- $\alpha 2$ C-AR heterodimers results in atypical Gs-PKA signaling. Nat. Chem. Biol. 2015, 11, 271-279. [CrossRef] [PubMed]

43. Baba, K.; Benleulmi-Chaachoua, A.; Journé, A.-S.; Kamal, M.; Guillaume, J.-L.; Dussaud, S.; Gbahou, F.; Yettou, K.; Liu, C.; Contreras-Alcantara, S.; et al. Heteromeric MT1/MT2 melatonin receptors modulate photoreceptor function. Sci. Signal. 2013, 6, ra89. [CrossRef]

44. Smith, N.J.; Milligan, G. Allostery at G protein-coupled receptor homo- and heteromers: Uncharted pharmacological landscapes. Pharmacol. Rev. 2010, 62, 701-725. [CrossRef] [PubMed]

45. León-Navarro, D.A.; Albasanz, J.L.; Martín, M. Functional Cross-Talk between Adenosine and Metabotropic Glutamate Receptors. Curr. Neuropharmacol. 2019, 17, 422-437. [CrossRef]

46. Galvez, T.; Duthey, B.; Kniazeff, J.; Blahos, J.; Rovelli, G.; Bettler, B.; Prézeau, L.; Pin, J.P. Allosteric interactions between GB1 and GB2 subunits are required for optimal GABA(B) receptor function. EMBO J. 2001, 20, 2152-2159. [CrossRef] [PubMed]

47. Gomes, I.; Jordan, B.A.; Gupta, A.; Trapaidze, N.; Nagy, V.; Devi, L.A. Heterodimerization of mu and delta opioid receptors: A role in opiate synergy. J. Neurosci. 2000, 20, RC110. [CrossRef] [PubMed]

48. Rocheville, M.; Lange, D.C.; Kumar, U.; Patel, S.C.; Patel, R.C.; Patel, Y.C. Receptors for dopamine and somatostatin: Formation of hetero-oligomers with enhanced functional activity. Science 2000, 288, 154-157. [CrossRef]

49. Franco, R.; Ferre, S.; Agnati, L.; Torvinen, M.; Gines, S.; Hillion, J.; Casado, V.; Lledo, P.-M.; Zoli, M.; Lluis, C.; et al. Evidence for Adenosine/Dopamine Receptor Interactions: Indications for Heteromerization. Neuropsychopharmacology 2000, 23, S50-S59. [CrossRef]

50. Navarro, G.; Quiroz, C.; Moreno-Delgado, D.; Sierakowiak, A.; McDowell, K.; Moreno, E.; Rea, W.; Cai, N.-S.; Aguinaga, D.; Howell, L.A.; et al. Orexin-corticotropin-releasing factor receptor heteromers in the ventral tegmental area as targets for cocaine. J. Neurosci. 2015, 35, 6639-6653. [CrossRef]

51. Martínez-Pinilla, E.; Rodríguez-Pérez, A.I.; Navarro, G.; Aguinaga, D.; Moreno, E.; Lanciego, J.L.; Labandeira-García, J.L.; Franco, R. Dopamine D2 and angiotensin II type 1 receptors form functional heteromers in rat striatum. Biochem. Pharmacol. 2015, 96, 131-142. [CrossRef]

52. Young, B.M.; Nguyen, E.; Chedrawe, M.A.J.; Rainey, J.K.; Dupré, D.J. Differential Contribution of Transmembrane Domains IV, V, VI, and VII to Human Angiotensin II Type 1 Receptor Homomer Formation. J. Biol. Chem. 2017, 292, 3341-3350. [CrossRef]

53. Borroto-Escuela, D.O.; Wydra, K.; Li, X.; Rodriguez, D.; Carlsson, J.; Jastrzębska, J.; Filip, M.; Fuxe, K. Disruption of A2AR-D2R Heteroreceptor Complexes After A2AR Transmembrane 5 Peptide Administration Enhances Cocaine Self-Administration in Rats. Mol. Neurobiol. 2018, 55, 7038-7048. [CrossRef] [PubMed]

54. Lee, L.T.O.; Ng, S.Y.L.; Chu, J.Y.S.; Sekar, R.; Harikumar, K.G.; Miller, L.J.; Chow, B.K.C. Transmembrane peptides as unique tools to demonstrate the in vivo action of a cross-class GPCR heterocomplex. FASEB J. 2014, 28, 2632-2644. [CrossRef]

55. Harikumar, K.G.; Pinon, D.I.; Miller, L.J. Transmembrane segment IV contributes a functionally important interface for oligomerization of the Class II G protein-coupled secretin receptor. J. Biol. Chem. 2007, 282, 30363-30372. [CrossRef] [PubMed]

56. Guidolin, D.; Marcoli, M.; Tortorella, C.; Maura, G.; Agnati, L.F. Receptor-Receptor Interactions as a Widespread Phenomenon: Novel Targets for Drug Development? Front. Endocrinol. 2019, 10, 53. [CrossRef] [PubMed]

57. Møller, T.C.; Hottin, J.; Clerté, C.; Zwier, J.M.; Durroux, T.; Rondard, P.; Prézeau, L.; Royer, C.A.; Pin, J.-P.; Margeat, E.; et al. Oligomerization of a $\mathrm{G}$ protein-coupled receptor in neurons controlled by its structural dynamics. Sci. Rep. 2018, 8, 10414. [CrossRef]

58. Guidolin, D.; Marcoli, M.; Tortorella, C.; Maura, G.; Agnati, L.F. G protein-coupled receptor-receptor interactions give integrative dynamics to intercellular communication. Rev. Neurosci. 2018, 29, 703-726. [CrossRef] 
59. Köfalvi, A.; Moreno, E.; Cordomí, A.; Cai, N.-S.; Fernández-Dueñas, V.; Ferreira, S.G.; Guixà-González, R.; Sánchez-Soto, M.; Yano, H.; Casadó-Anguera, V.; et al. Control of glutamate release by complexes of adenosine and cannabinoid receptors. BMC Biol. 2020, 18, 9. [CrossRef]

60. Wan, L.; Xu, F.; Liu, C.; Ji, B.; Zhang, R.; Wang, P.; Wu, F.; Pan, Y.; Yang, C.; Wang, C.; et al. Transmembrane peptide 4 and 5 of APJ are essential for its heterodimerization with OX1R. Biochem. Biophys. Res. Commun. 2020, 521, 408-413. [CrossRef] [PubMed]

61. Cai, X.; Bai, B.; Zhang, R.; Wang, C.; Chen, J. Apelin receptor homodimer-oligomers revealed by single-molecule imaging and novel G protein-dependent signaling. Sci. Rep. 2017, 7, 40335. [CrossRef] [PubMed]

62. Navarro, G.; Cordomí, A.; Brugarolas, M.; Moreno, E.; Aguinaga, D.; Pérez-Benito, L.; Ferre, S.; Cortés, A.; Casadó, V.; Mallol, J.; et al. Cross-communication between Gi and Gs in a G-protein-coupled receptor heterotetramer guided by a receptor C-terminal domain. BMC Biol. 2018, 16, 24. [CrossRef] [PubMed]

63. McMillin, S.M.; Heusel, M.; Liu, T.; Costanzi, S.; Wess, J. Structural basis of M3 muscarinic receptor dimer/oligomer formation. J. Biol. Chem. 2011, 286, 28584-28598. [CrossRef] [PubMed]

64. Harikumar, K.G.; Dong, M.; Cheng, Z.; Pinon, D.I.; Lybrand, T.P.; Miller, L.J. Transmembrane Segment Peptides Can Disrupt Cholecystokinin Receptor Oligomerization without affecting Receptor Function. Biochemistry 2006, 45, 14706-14716. [CrossRef] [PubMed]

65. Hernanz-Falcón, P.; Rodríguez-Frade, J.M.; Serrano, A.; Juan, D.; del Sol, A.; Soriano, S.F.; Roncal, F.; Gómez, L.; Valencia, A.; Martínez-A, C.; et al. Identification of amino acid residues crucial for chemokine receptor dimerization. Nat. Immunol. 2004, 5, 216-223. [CrossRef]

66. Jastrzebska, B.; Chen, Y.; Orban, T.; Jin, H.; Hofmann, L.; Palczewski, K. Disruption of Rhodopsin Dimerization with Synthetic Peptides Targeting an Interaction Interface. J. Biol. Chem. 2015, 290, 25728-25744. [CrossRef] [PubMed]

67. Petersen, J.; Wright, S.C.; Rodríguez, D.; Matricon, P.; Lahav, N.; Vromen, A.; Friedler, A.; Strömqvist, J.; Wennmalm, S.; Carlsson, J.; et al. Agonist-induced dimer dissociation as a macromolecular step in G protein-coupled receptor signaling. Nat. Commun. 2017, 8, 226. [CrossRef] [PubMed]

68. He, S.-Q.; Zhang, Z.-N.; Guan, J.-S.; Liu, H.-R.; Zhao, B.; Wang, H.-B.; Li, Q.; Yang, H.; Luo, J.; Li, Z.-Y.; et al. Facilitation of mu-opioid receptor activity by preventing delta-opioid receptor-mediated codegradation. Neuron 2011, 69, 120-131. [CrossRef]

69. Erak, M.; Bellmann-Sickert, K.; Els-Heindl, S.; Beck-Sickinger, A.G. Peptide chemistry toolbox-Transforming natural peptides into peptide therapeutics. Bioorg. Med. Chem. 2018, 26, 2759-2765. [CrossRef]

70. Ross, J.N.; Fields, F.R.; Kalwajtys, V.R.; Gonzalez, A.J.; O’Connor, S.; Zhang, A.; Moran, T.E.; Hammers, D.E.; Carothers, K.E.; Lee, S.W. Synthetic Peptide Libraries Designed From a Minimal Alpha-Helical Domain of AS-48-Bacteriocin Homologs Exhibit Potent Antibacterial Activity. Front. Microbiol. 2020, 11, 2714. [CrossRef]

71. Zhang, X.; Bathgate, R.A.D.; Hossain, M.A. Human Insulin-like Peptide 5 (INSL5). Identification of a Simplified Version of Two-Chain Analog A13. ACS Med. Chem. Lett. 2020, 11, 2455-2460. [CrossRef]

72. Lu, Z.; Xu, J.; Rossi, G.C.; Majumdar, S.; Pasternak, G.W.; Pan, Y.-X. Mediation of opioid analgesia by a truncated 6-transmembrane GPCR. J. Clin. Investig. 2015, 125, 2626-2630. [CrossRef] [PubMed]

73. Yadav, D.; Dewangan, H.K. PEGYLATION: An important approach for novel drug delivery system. J. Biomater. Sci. Polym. Ed. 2021, 32, 266-280. [CrossRef]

74. Manteghi, R.; Pallagi, E.; Olajos, G.; Csóka, I. Pegylation and formulation strategy of Anti-Microbial Peptide (AMP) according to the quality by design approach. Eur. J. Pharm. Sci. Off. J. Eur. Fed. Pharm. Sci. 2020, 144, 105197. [CrossRef] [PubMed]

75. Bhosle, G.S.; Nawale, L.; Yeware, A.M.; Sarkar, D.; Fernandes, M. Antibacterial and anti-TB tat-peptidomimetics with improved efficacy and half-life. Eur. J. Med. Chem. 2018, 152, 358-369. [CrossRef] [PubMed]

76. Lu, J.; Xu, H.; Xia, J.; Ma, J.; Xu, J.; Li, Y.; Feng, J. D- and Unnatural Amino Acid Substituted Antimicrobial Peptides With Improved Proteolytic Resistance and Their Proteolytic Degradation Characteristics. Front. Microbiol. 2020, 11, 2869. [CrossRef] [PubMed]

77. Doti, N.; Mardirossian, M.; Sandomenico, A.; Ruvo, M.; Caporale, A. Recent Applications of Retro-Inverso Peptides. Int. J. Mol. Sci. 2021, 22, 8677. [CrossRef]

78. Arranz-Gibert, P.; Ciudad, S.; Seco, J.; García, J.; Giralt, E.; Teixidó, M. Immunosilencing peptides by stereochemical inversion and sequence reversal: Retro-D-peptides. Sci. Rep. 2018, 8, 6446. [CrossRef]

79. Li, X.; Wang, S.; Zhu, X.; Zhangsun, D.; Wu, Y.; Luo, S. Effects of Cyclization on Activity and Stability of $\alpha$-Conotoxin TxIB. Mar. Drugs 2020, 18, 180. [CrossRef]

80. Gallo, M.; Defaus, S.; Andreu, D. 1988-2018: Thirty years of drug smuggling at the nano scale. Challenges and opportunities of cell-penetrating peptides in biomedical research. Arch. Biochem. Biophys. 2018, 661, 74-86. [CrossRef]

81. Aziz, Z.A.B.A.; Ahmad, A.; Mohd-Setapar, S.H.; Hassan, H.; Lokhat, D.; Kamal, M.A.; Ashraf, G.M. Recent Advances in Drug Delivery of Polymeric Nano-Micelles. Curr. Drug Metab. 2017, 18, 16-29. [CrossRef]

82. Cao, S.-J.; Xu, S.; Wang, H.-M.; Ling, Y.; Dong, J.; Xia, R.-D.; Sun, X.-H. Nanoparticles: Oral Delivery for Protein and Peptide Drugs. AAPS PharmSciTech 2019, 20, 190. [CrossRef]

83. Choudhary, A.; Raines, R.T. An evaluation of peptide-bond isosteres. Chembiochem 2011, 12, 1801-1807. [CrossRef]

84. Altman, R.A.; Sharma, K.K.; Rajewski, L.G.; Toren, P.C.; Baltezor, M.J.; Pal, M.; Karad, S.N. Tyr(1)- $\psi[(Z) C F=C H]-G l y(2)$ Fluorinated Peptidomimetic Improves Distribution and Metabolism Properties of Leu-Enkephalin. ACS Chem. Neurosci. 2018, 9, 1735-1742. [CrossRef] [PubMed] 
85. Maisel, S.A.; Broka, D.; Atwell, B.; Bunch, T.; Kupp, R.; Singh, S.K.; Mehta, S.; Schroeder, J. Stapled EGFR peptide reduces inflammatory breast cancer and inhibits additional HER-driven models of cancer. J. Transl. Med. 2019, 17, 201. [CrossRef] [PubMed]

86. Findeisen, F.; Campiglio, M.; Jo, H.; Abderemane-Ali, F.; Rumpf, C.H.; Pope, L.; Rossen, N.D.; Flucher, B.E.; DeGrado, W.F.; Minor, D.L.J. Stapled Voltage-Gated Calcium Channel $(\mathrm{Ca}(\mathrm{V})) \alpha$-Interaction Domain (AID) Peptides Act As Selective Protein-Protein Interaction Inhibitors of $\mathrm{Ca}(\mathrm{V})$ Function. ACS Chem. Neurosci. 2017, 8, 1313-1326. [CrossRef]

87. Moiola, M.; Memeo, M.G.; Quadrelli, P. Stapled Peptides-A Useful Improvement for Peptide-Based Drugs. Molecules 2019, 24, 3654. [CrossRef] [PubMed]

88. Botta, J.; Bibic, L.; Killoran, P.; McCormick, P.J.; Howell, L.A. Design and development of stapled transmembrane peptides that disrupt the activity of G-protein-coupled receptor oligomers. J. Biol. Chem. 2019, 294, 16587-16603. [CrossRef]

89. Lynch, M.E.; Campbell, F. Cannabinoids for treatment of chronic non-cancer pain; a systematic review of randomized trials. Br. J. Clin. Pharmacol. 2011, 72, 735-744. [CrossRef]

90. Skrabek, R.Q.; Galimova, L.; Ethans, K.; Perry, D. Nabilone for the treatment of pain in fibromyalgia. J. Pain 2008, 9, 164-173. [CrossRef]

91. Ware, M.A.; Fitzcharles, M.-A.; Joseph, L.; Shir, Y. The effects of nabilone on sleep in fibromyalgia: Results of a randomized controlled trial. Anesth. Analg. 2010, 110, 604-610. [CrossRef] [PubMed]

92. Hampson, R.E.; Deadwyler, S.A. Cannabinoids, hippocampal function and memory. Life Sci. 1999, 65, 715-723. [CrossRef]

93. Busquets-Garcia, A.; Puighermanal, E.; Pastor, A.; de la Torre, R.; Maldonado, R.; Ozaita, A. Differential role of anandamide and 2-arachidonoylglycerol in memory and anxiety-like responses. Biol. Psychiatry 2011, 70, 479-486. [CrossRef]

94. Puighermanal, E.; Busquets-Garcia, A.; Maldonado, R.; Ozaita, A. Cellular and intracellular mechanisms involved in the cognitive impairment of cannabinoids. Philos. Trans. R. Soc. Lond. B Biol. Sci. 2012, 367, 3254-3263. [CrossRef] [PubMed]

95. Moreira, F.A.; Lutz, B. The endocannabinoid system: Emotion, learning and addiction. Addict. Biol. 2008, 13, 196-212. [CrossRef]

96. Gallo, M.; Moreno, E.; Defaus, S.; Ortega-Alvaro, A.; Gonzalez, A.; Robledo, P.; Cavaco, M.; Neves, V.; Castanho, M.A.R.B.; Casadó, V.; et al. Orally Active Peptide Vector Allows Using Cannabis to Fight Pain While Avoiding Side Effects. J. Med. Chem. 2021, 64, 6937-6948. [CrossRef] [PubMed]

97. Gallo, M.; Navarro, G.; Franco, R.; Andreu, D. A2A Receptor Homodimer-Disrupting Sequence Efficiently Delivered by a Protease-Resistant, Cyclic CPP Vector. Int. J. Mol. Sci. 2019, 20, 4937. [CrossRef]

98. Ferre, S.; Ciruela, F.; Borycz, J.; Solinas, M.; Quarta, D.; Antoniou, K.; Quiroz, C.; Justinova, Z.; Lluis, C.; Franco, R.; et al. Adenosine A1-A2A receptor heteromers: New targets for caffeine in the brain. Front. Biosci. 2008, 13, 2391-2399. [CrossRef]

99. Ferré, S.; Quiroz, C.; Woods, A.S.; Cunha, R.; Popoli, P.; Ciruela, F.; Lluis, C.; Franco, R.; Azdad, K.; Schiffmann, S.N. An update on adenosine A2A-dopamine D2 receptor interactions: Implications for the function of G protein-coupled receptors. Curr. Pharm. Des. 2008, 14, 1468-1474. [CrossRef]

100. Casadó-Anguera, V.; Bonaventura, J.; Moreno, E.; Navarro, G.; Cortés, A.; Ferré, S.; Casadó, V. Evidence for the heterotetrameric structure of the adenosine A2A-dopamine D2 receptor complex. Biochem. Soc. Trans. 2016, 44, 595-600. [CrossRef]

101. Torvinen, M.; Marcellino, D.; Canals, M.; Agnati, L.F.; Lluis, C.; Franco, R.; Fuxe, K. Adenosine A2A receptor and dopamine D3 receptor interactions: Evidence of functional A2A/D3 heteromeric complexes. Mol. Pharmacol. 2005, 67, 400-407. [CrossRef] [PubMed]

102. Aso, E.; Fernández-Dueñas, V.; López-Cano, M.; Taura, J.; Watanabe, M.; Ferrer, I.; Luján, R.; Ciruela, F. Adenosine A(2A)Cannabinoid CB(1) Receptor Heteromers in the Hippocampus: Cannabidiol Blunts $\Delta(9)$-Tetrahydrocannabinol-Induced Cognitive Impairment. Mol. Neurobiol. 2019, 56, 5382-5391. [CrossRef]

103. Moreno, E.; Chiarlone, A.; Medrano, M.; Puigdellívol, M.; Bibic, L.; Howell, L.A.; Resel, E.; Puente, N.; Casarejos, M.J.; Perucho, J.; et al. Singular Location and Signaling Profile of Adenosine A(2A)-Cannabinoid CB(1) Receptor Heteromers in the Dorsal Striatum. Neuropsychopharmacol. Off. Publ. Am. Coll. Neuropsychopharmacol. 2018, 43, 964-977. [CrossRef]

104. Márquez-Gómez, R.; Robins, M.T.; Gutiérrez-Rodelo, C.; Arias, J.-M.; Olivares-Reyes, J.-A.; van Rijn, R.M.; Arias-Montaño, J.-A. Functional histamine $\mathrm{H}(3)$ and adenosine $\mathrm{A}(2 \mathrm{~A})$ receptor heteromers in recombinant cells and rat striatum. Pharmacol. Res. 2018, 129, 515-525. [CrossRef]

105. Łukasiewicz, S.; Błasiak, E.; Faron-Górecka, A.; Polit, A.; Tworzydło, M.; Górecki, A.; Wasylewski, Z.; Dziedzicka-Wasylewska, M. Fluorescence studies of homooligomerization of adenosine A2A and serotonin 5-HT1A receptors reveal the specificity of receptor interactions in the plasma membrane. Pharmacol. Rep. 2007, 59, 379-392. [PubMed]

106. Ferre, S.; Ciruela, F.; Woods, A.S.; Canals, M.; Burgueno, J.; Marcellino, D.; Karcz-Kubicha, M.; Hope, B.T.; Morales, M.; Popoli, P.; et al. Glutamate mGlu5-Adenosine A2A-Dopamine D2 Receptor Interactions in the Striatum. Implications for Drug Therapy in Neuro-psychiatric Disorders and Drug Abuse. Curr. Med. Chem.-Cent. Nerv. Syst. Agents 2003, 3, 1-26. [CrossRef]

107. Ferré, S.; Goldberg, S.R.; Lluis, C.; Franco, R. Looking for the role of cannabinoid receptor heteromers in striatal function. Neuropharmacology 2009, 56 (Suppl. S1), 226-234. [CrossRef]

108. Borroto-Escuela, D.O.; Hinz, S.; Navarro, G.; Franco, R.; Müller, C.E.; Fuxe, K. Understanding the Role of Adenosine A2AR Heteroreceptor Complexes in Neurodegeneration and Neuroinflammation. Front. Neurosci. 2018, 12, 43. [CrossRef]

109. Atangcho, L.; Navaratna, T.; Thurber, G.M. Hitting Undruggable Targets: Viewing Stabilized Peptide Development through the Lens of Quantitative Systems Pharmacology. Trends Biochem. Sci. 2019, 44, 241-257. [CrossRef] 
110. Nischan, N.; Herce, H.D.; Natale, F.; Bohlke, N.; Budisa, N.; Cardoso, M.C.; Hackenberger, C.P.R. Covalent attachment of cyclic TAT peptides to GFP results in protein delivery into live cells with immediate bioavailability. Angew. Chem. Int. Ed. Engl. 2015, 54, 1950-1953. [CrossRef] [PubMed]

111. Qian, Z.; Martyna, A.; Hard, R.L.; Wang, J.; Appiah-Kubi, G.; Coss, C.; Phelps, M.A.; Rossman, J.S.; Pei, D. Discovery and Mechanism of Highly Efficient Cyclic Cell-Penetrating Peptides. Biochemistry 2016, 55, 2601-2612. [CrossRef] [PubMed] 